Social Sciences on Contemporary Turkey

18 | 2014

(Hi)stories of Honor in Ottoman Societies

\title{
Building Professional and Political Communities: The Value of Honor in the Self-Representation of Ottoman Police during the Second Constitutional Period
}

Noémi Lévy-Aksu

\section{(2) OpenEdition \\ Journals}

Electronic version

URL: http://journals.openedition.org/ejts/4895

DOI: $10.4000 /$ ejts.4895

ISSN: $1773-0546$

Publisher

EJTS

Electronic reference

Noémi Lévy-Aksu, «Building Professional and Political Communities: The Value of Honor in the SelfRepresentation of Ottoman Police during the Second Constitutional Period », European Journal of Turkish Studies [Online], 18 | 2014, Online since 01 July 2014, connection on 16 February 2020. URL: http://journals.openedition.org/ejts/4895; DOI : 10.4000/ejts.4895

This text was automatically generated on 16 February 2020.

(c) Some rights reserved / Creative Commons license 


\title{
Building Professional and Political Communities: The Value of Honor in the Self-Representation of Ottoman Police during the Second Constitutional Period
}

\author{
Noémi Lévy-Aksu
}

1 This article focuses on the use of honor and related concepts in sources written by members of the Ottoman police forces during the Young Turk period, a period that witnessed the complete reformation of the police institution in the Empire. It argues that the concept of honor emerged as a central value around which the promotion of individual, professional and political identities was articulated. Referring to personal qualities and political values, the notion of "nâmûs" (honor) was used by the authors of textbooks, short self-narratives or longer autobiographies to legitimize both their role in the police force as well as the larger role of the institution in society. This two-fold dimension was based on the rhetoric of inclusion and exclusion alike, for it constantly juxtaposed the honorable policemen of the new regime to various groups they construed as dishonorable, including the policemen of the previous regime and the political opponents of the present. This essay aims to highlight the multi-dimensional uses of the notion of honor, investigating its social and political significance for the newly-fashioned, professional identity of the Ottoman police forces in the post-1908 era.

2 Anthropologists and their critics have long debated the concept of honor for defining and characterizing Mediterranean societies. ${ }^{1}$ The criticism against the view of honor as an anthropological and social object defining "Mediterranean culture" has led scholars to question the very relevance of the concept of the Mediterranean, and, along with it, the utility of the concept of honor and other moral concepts they consider a-historical and essentialist. 
3 Acknowledging some of the pitfalls anthropologists took for granted in addressing honor in Mediterranean cultures, scholars are revisiting the concept of honor in historical studies dealing with various geographies, including the Ottoman Empire. Separated from the emphasis on traditional and immutable cultural forms, honor has made a comeback as a means of understanding changing balances in the political and social arrangements of various states and regions throughout the modern era. ${ }^{2}$ Attempts to conceptualize historically associations among the state, society and honor have focused primarily on two spheres and their related institutions: justice and the military. Works on justice point out the fluidity of the concept and the difficulties in establishing a clear dichotomy between the traditional and the modern, or the illicit and the legal. They also investigate the role played by the notion of honor and morality in the discourses and strategies developed by the state and local actors to legitimize their positions in the community or exclude deviant individuals or groups on political and moral grounds (Peirce 2003; Tuğ 2009). As for the imbrications between governance and crime, honor has been one of the notions used by studies on paramilitary groups such as bandits to point to the convergences in the ways violence is performed and legitimized, examples of which can be found among state military forces and illegal organizations (Esmer 2009). ${ }^{3}$ The use of honor as a tool for military and social mobilization has also been studied primarily for the period of the first World War (Beşikçi 2012), although recent work has also begun to point to earlier versions of the use of honor to advance patriotic pride in the Ottoman state, for example, during the Crimean War (Badem 2010: 394-402).

4 Many of the themes and questions raised by studies of judicial and military values are also relevant for the police, an institution closely related to military and judicial institutions both in its missions and general characteristics. The question of the role that ethics and morality have played in police organization and activities has been explored by historians, sociologists and members of the police themselves in many contexts, including the Turkish one (Bal, Beren 2003). Nonetheless, at least for the Ottoman case, no work has yet investigated the moral values that the Ottoman police promoted during the period of late-nineteenth- and early-twentieth-century reforms. My paper aims to highlight the importance of the theme of honor in the reform and legitimization of the Ottoman police at the beginning of the Young Turk era. In the pages that follow, I contend that the notion of honor, as it appears in late Ottoman police sources, was instrumental to the project of building two new communities, one political and the other professional. Defined as the common denominator characterizing the members of the police as well as their practices and relationships with the people, references to the value of honor also allowed police in the new Ottoman regime to stigmatize and exclude those they considered their enemies from different professional and political communities. This essay is an attempt to understand better the several layers of the rhetoric of inclusion and exclusion that surround the notion of honor, taking the police force of the early Young Turk period as its case study.

5 This paper focuses on discourses, and I am aware of the risks and limitations of discourse analysis, especially when discourses emanate from official sources. Nevertheless, I believe that these sources, which have until now been mostly overlooked, deserve to be taken into account for several reasons. First, their very existence has a political and institutional meaning. For the first time in its brief history, 
after 1908, the Ottoman police started to develop a public discourse of their own. This had to do with the change of regime, but there were other factors informing this new self-fashioning as well. After all, the Ministry of Justice had started to publish its official journal in 1873, the Gazette of the Courts (Ceride-i mehakim), aiming to diffuse knowledge of the new regulations and legal procedures among the members of the institution (Rubin 2011). In the case of the Ottoman police, the fact that a professional journal and textbooks started to be published during the Second Constitutional Period was not a coincidence; it rather reflected the new status which the Ottoman police started to acquire within the government marked by increased financial resources and a wider scope of jurisdiction in society (Ergut 2004: 152-228).

6 The centrality of the theme of honor in the police sources of the time also has explicit and implicit connections with some significant transformations in the political and social role of the police after the Young Turk revolution. Nobody would have expected the police officers to describe themselves as shameful or vile, and the exaltation of virtue and virility is part of the topoi used by police institutions all over the world. Nevertheless, clichés too have the potential to illuminate their historical context when their articulation to other notions and social realities allows one to move beyond the level of self-representation. In the case of the Ottoman police, I argue that the theme of honor is to be connected to the notions of accountability and political legitimacy, a new perspective on policing which emerged after the Young Turk revolution. My paper discusses the political and practical implications of these notions, which have until so far been analyzed either in terms of professionalization (Ergut 2004) or democratization (Bal, Beren 2003).

7 Finally, the discursive importance of honor in these sources points to one of the major social challenges which were faced by the police of the time: the struggle against local individuals and groups for the control of urban space. Strong-arm men and more or less organized gangs were a legacy of the Hamidian period that emerged as the main threat to public order in the immediate aftermath of the Revolution. In many cases, the trouble-makers benefited from a social and spatial integration which made them part of an "urban culture", to follow Roger Deal's conceptualization for the phenomenon in the Hamidian Istanbul (Deal 2010). Informed by violence and illicit behavior, this urban culture also heavily relied on the theme of honor for its hierarchical organization, use of violence and exaltation of masculinity (Lévy-Aksu 2013). The suppression of these groups was all but a smooth process in the first years of the Second Constitutional period. In this respect, the struggle on the ground was echoed by an offensive on paper. Through the political connections made by the police official sources dealing with these "dishonorable" categories, this discourse of exclusion raises the question of the borders of the professional and national communities promoted in the police sources of the time.

8 Before analyzing the way that the rhetoric of honor appeared in these late Ottoman police narratives, I will briefly contextualize these texts and their authors within the broader framework of the emergence of the Ottoman police force, which, by the midnineteenth century, became one of the major institutions in charge of implementing Tanzimat principles of protecting individuals, honor and property.

9 The second part of my paper will concentrate on the role of honor in the construction of a positive police identity. The value of honor was instrumental in the emergence of an Ottoman discourse on police ethics during the second constitutional era. Parallel to 
the energy invested in the professional formation of members of the police, the stress on the moral qualities necessary to form part of the police served two purposes, both marking the rupture with the turpitudes of the previous regime and simultaneously enhancing the legitimacy of the new institution, whose activities were to be shaped by the principles of the new regime.

In the last part of the essay, I will show that this emphasis on the value of honor was also a way to stigmatize and exclude certain groups or individuals, an aspect which, though less explicit than self-promotion, was equally central in the construction of a professional and political community in the narratives under study. I will argue that, beyond offering a literary means of emphasizing the virtue of authors confronting dangerous enemies, this negative approach to honor must also be taken into account in the evaluation of the political orientations of the late Ottoman police and its relationship with society in general during the Empire's second constitutional period.

\section{Protecting life, honor and property: police forces as newcomers into the Circle of Justice}

11 The redefinition of the relationship between the Ottoman state and its subjects was at the core of the Tanzimat reforms. Through the 1839 and 1856 edicts, as well as multiple legal and administrative reforms, the political and social bases of the Ottoman regime were transformed. The details of this process, which articulated traditional Islamic and Ottoman concepts and European references, are beyond the scope of this paper. Here, I focus on the role attributed to the newly created police forces in this transformed political framework.

12 Several studies have explored the transformations that the Tanzimat reforms introduced into the mechanisms of state legitimization and the traditional "Circle of Justice" that linked the sultan to his subjects (Reinkowski 2005: 200-203; Miller 2005; Darling 2013). Most of these studies lay stress on legal reforms. The extensive reformation of the Ottoman justice system, which manifested itself through the adoption of new codes and a thorough reform of judicial procedure, offers a valuable window into the new idiom of power and law that emerged during the Tanzimat era. However, less studied than justice and law, the role of the police within this process was hardly insignificant. In charge of law enforcement and the protection of state interests and subjects' lives and property, the police held a central position in the new mechanisms of control and surveillance over the population. Following the suppression of the Janissaries in 1826, the institutionalization of the police forces, officially created by the 1845 Polis Nizamnamesi, was a slow process only completed in the early 20th century (Alyot 1947).

13 The few brief police regulations published before the second constitutional period offer only a partial picture of the missions with which the state entrusted the police during this period. They nonetheless make clear that the police force's main tasks pertained to the implementation, preservation and restoration of the political, social and moral order. In their various articles, the 1845, 1879, 1896 and 1907, police regulations juxtaposed and articulated several concepts closely related to public order, discipline and security, such as nizam, asayiş, emniyet, inzibat, all of which appeared in the first articles of the regulations defining the aim of police activity. The remaining articles 
provided information on the concrete meaning of those concepts as far as policing was concerned. In the 1845 regulation, the priorities of police activities were defined as the control and surveillance of the population and the prevention or suppression of social unrest and deviant behavior such as begging and gambling (Ergin 1995: 875-878). Until 1879 , a unique force, with a strong military character, was in charge of policing urban and rural spaces. Initially conceived as a kind of militia whose main aim was to face the challenge of bandits and rural unrest, the zabtiye became more and more involved in civil policing and crime investigation as well, until the 1879 reforms which created a distinct ministry of Police (Zabtiye Nezareti) and a gendarmerie force under the authority of the ministry of War (Paz 2010: 170-225).

The regulations published under the reign of Abdülhamid II gave great importance to the defense of state interests through the surveillance and suppression of political opponents, although various aspects of social and moral control were also listed among the duties of police forces. In all of these regulations, the fight against crime was a secondary topic, only mentioned in the last article of the 1845 regulation and still in the background in texts that followed. ${ }^{4}$ Much stressed by Ferdan Ergut as a distinctive feature of the Ottoman-Turkish police, the predominance of social control over crime resolution was actually shared by most national and imperial police systems organized or reformed in the 19th century (Ergut 2004; Berlière 1993).

In this context, cases related to morality became one of the major fields of police intervention in Ottoman realms as well. In the absence of codes, self-narratives or pedagogical publications that might highlight the principles underlying police activity before 1908, only police reports offer insights into the concepts of order and disorder that shaped these interventions. In these laconic sources, various minor disorders are assimilated into the negation of moral values and codes. Negative expressions related to morality, such as the omnipresent uygunsuz (improper) or uygunsuzluk (impropriety), are used to stigmatize behaviors, events and individuals, ranging from drunkenness, prostitution, and indecent dress to state officials' neglecting their duties. Many of the behaviors labeled as improper in the police reports did not constitute clear breaches of the law but were instead denounced as infringements of the social and moral order.

The determination of what was proper or improper was to a large extent left to the personal judgment of the local police officer. That definition made it much more flexible and open to negotiation than the letter of the law, but it also opened the door to arbitrary police abuses. ${ }^{5}$ Alongside the concept of uygunsuzluk, negative forms of words such as ahlâk (morals), adâb (good manner) and münasebet (convenience) were also omnipresent in late 19th-century police reports. They clearly demonstrate that under the reign of Abdülhamid II, the police did not only focus on the surveillance and repression of political opponents but also (indeed mostly) on the prevention and repression of the violations of an ideal, though undefined, social and moral order.

The Young Turk revolution did not dramatically change the general framework regulating police activities in the Empire. Although the new regime dismissed Abdülhamid II's most infamous spies and significantly reformed the police forces in August 1909 by dissolving the Police Ministry and replacing it with the General Directorate of Security (Emniyet-i Umumiye Müdüriyeti), social and moral control remained at the core of police missions. For example, this is attested by the law on beggars and suspect individuals adopted in 1909. This law gave the police the power to apprehend and repress such individuals (Ergut 2002: 161-163). The very fact that this 
new law grouped beggars and recidivists together and criminalized them on the ground of their persons rather than their acts illustrates the blurring of the boundaries between illegality and immorality mentioned above. Because they were considered to be unattached, depraved and unproductive, beggars and repeat offenders became the objects of summary trials, expulsion, prison and even physical punishment (Ergut 2002; Özbek 2009).

If there were a clear continuity in the definition of the social order "defended" by the police during the Tanzimat, Hamidian and Young Turk periods, the institution gained a much more efficient means of performing its missions during the last period: the rise in the number of police and the efforts made in the professionalization of the institution through the creation of police schools, the stipulation of conditions for recruitment and advancement, as well as the rise in wages were all indications of the importance the new regime invested in the police as vectors of a greater control of society.

This process of professionalization had its discursive counterpart in the emergence of several kinds of publications through which the police produced a discourse about themselves and attempted to highlight and justify various aspects of their activities. In the years that followed the 1908 revolution, a police journal as well as several textbooks on the subject began to appear for use in newly established police schools. These sources provide us with insights into the perceptions and definitions of policing on the part of members of the institution, something that is missing for earlier periods. With their contents (i.e., their rhetoric and their visual materials) they help give us a better understanding of the modalities and aims of policing during this period. At the same time, they also became the vectors of a new strategy of communication that aimed to legitimize the police as an intermediary between state and society. Relying more specifically on three police textbooks published between 1910 and 1913, and two autobiographies written by police officers during this period, I argue that despite their differences in length and content, these disparate sources articulated a similar rhetoric of honor and morality which constituted the basis for their claim that members of the police were the most legitimate and efficient intermediaries between state and society in the new regime. At a time when foreign and local detective stories flourished in the Ottoman Empire, police officers who put pen to paper appear to have cared very little about appearing as the new Sherlock Holmes, preferring instead to present themselves as honorable men, guided by political and moral ideals and defending the common interests of the state and the people. ${ }^{6}$ The second part of my paper will study the use of honor in these narratives in greater detail.

\section{Building professional and political communities}

The words "nâmûs" (honor), "nâmûslu", "nâmûskâr" (honorable) and their synonyms constitute one of the major semantic fields in police literature of the second constitutional period. ${ }^{7}$ Disparate authors' simultaneous insistence on these concepts tells us as much about their motivations for writing such self-narratives as they do about the ideological views underlying them. Below I will analyze the professional and political implications of this centrality of honor.

21 First, in most of these texts, the notion of honor is part of a revolutionary rhetoric that aimed to stress the rupture between the shameful old regime of Abdülhamid II and the glorious constitutional present. Notable in many aspects of public life, this dual 
opposition between the past and the present is nowhere more present than in police narratives for obvious reasons. Used by Abdülhamid II to protect state interests, suppress political opponents and enhance social control, the police were one of the most criticized institutions after the 1908 revolution. While the first purges occurred at the end of the summer, both the newspapers and the parliamentary debates stressed the need for a vast reform of the institution, which would be the only way to restore its lost credibility. As mentioned above, one year later, in August 1909, the Police Ministry was replaced by a Directorate of Public Security, under the authority of the Ministry of Interior (Lévy-Aksu 2013: 165-190). The publications under study emanate from members of this reformed institution. Most can be considered official publications, since they belonged to textbooks used in newly created police schools.

According to those narratives, the old regime police was corrupt, brutal and unjust; put another way, they were deprived of honor, or "nâmûssuz", as in the two following quotations:

"They were the old police. In the eyes of the people they were worthless, but they behaved against the people like cold-hearted monsters, like tyrants, traitors, liars, robbers, and opportunistic creatures without any humanity, and they used the people as their slaves." ${ }^{8}$

"The police were for me the most despicable, worthless, tyrannical and vile creatures! [...] oh, creatures without any honor [nâmûssuz mahlûklar]".

The duty of the new police was to clean the stain left on the institution, hence the desire to prove that policemen could be paragons of morality. In the sources discussed below, "honorable" policemen are almost consistently juxtaposed to police from the previous era: understanding the sacred nature of their work, refusing any kind of bribe, showing all due respects to the people, they perfectly embody the value of honor. This point was stressed by Nazif Efendi, a policeman working at the Samatya police station, inviting his fellow policemen to act "always honorable" at the end of his short selfnarrative published within İbrahim Feridun's textbook:

"The only ones able to represent the law of the country, to risk their lives in all catastrophes, to ensure common tranquility and national prosperity are the police. My friends, always act honorably!"10

Beyond the opposition between the depravity of the past and the morality brought back by the new regime, the concept of honor also pointed to the personal qualities required by individuals eager to enter the police force. Although none of the authors denied the importance of professional formation, they all stressed that education could by no means be sufficient to create a good police officer. Courage, honesty, and fairness were described as the innate virtues required to enter and thrive in the police force. According to Hüseyin Hakk1, one should prefer that "rather than being learned, the police be of 'excellent morality"' (hüsn-ı ahlâk sâhibi) so that they could perform their duty properly:

"The police serve the country with its excellent knowledge. However, one can never assume that knowledge is sufficient to be a policeman. What is necessary and required is, together with-and even more-than knowledge, the quality of the soul and the excellence of the conscience. Ignorant people are not the only ones who can be characterized by their immorality, evilness of the soul, or mediocrity of the spirit. In order that the police may be useful and valuable for the country, rather than being learned, one must wish that they be of excellent morality". ${ }^{11}$

Stress on the personal qualities, respectability and moral exemplarity of state officials had been a key aspect of reform and the development of Ottoman bureaucracy and 
state apparatuses since the Tanzimat period. Several scholars have argued convincingly that the legal reforms and adoption of new penal codes were first and foremost directed at the repression of abuses and misbehaviors of state officials, such as corruption and the disproportionate use of violence. This orientation acknowledged the crucial role of the actors of various state administrations in the legitimization of the regime and the eradication of illicit practices in society as a whole (Kırl 2006; Miller 2005). The importance given to morality also showed itself through the codified and informal conditions of recruitment specific to each institution. The wide-spread use of recommendations and kefil (sponsors) for new recruits provided them with a certificate of morality while tightening power relationships among bureaucratic elites. In the last quarter of the 19th century, when most of the state institutions were endowed with regulations elaborating the criteria for entering such careers, "excellent morality" had become one of the standard requirements. For instance, the 1907 police regulation which listed the desired attributes of a policeman mentioned not only a man's age or physical condition but also suggested that he should possess "excellent morality" (hüsn-i ahlâk) (Alyot 1947: 197). Similar references continued to be present in regulations issued during the Second Constitutional period, which inherited the rhetoric of morality of the previous regime and transformed the moralization of the state institutions into a political priority.

While praising that process of moralization, police self-narratives did not overlook the obstacles that arose in the process. According to the authors, the police force's most pressing problem was finding honorable and respectable men. "Improper" (uygunsuz) behavior such as the disrespect of working hours or the frequenting of coffeehouses during work was denounced as manifestations of ignoble characters, which stained the image of the institution. This point shows us the limits of the rhetoric opposing the old and the new police. Moreover, certain members of new police forces had previously served as members of the Hamidian regime. Indeed, the state archives clearly show that the purges undertaken in 1908-1909 were far from systematic or comprehensive: most of the individuals purged at that time were former spies or high-ranking officers, some of whom were reintegrated into imperial forces a few months later. ${ }^{12}$ The main reasons for this low turn-over was that the police schools were not yet fully functioning, while the image of the police was still very negative, making it difficult to find competent and honest new recruits. By announcing an increase in police salaries in late 1909 , the authorities attempted to make policing more attractive to worthy candidates. Yet this was only a partial answer to the recruitment problem. The transfer of officers and soldiers from the army to the police proved to be a more efficient solution. It not only provided the police with well-trained, disciplined and supposedly high-spirited recruits but also strengthened the link between the two institutions and contributing to the spread of military values among members of civil society, a major goal of Young Turk policy after 1909 (Ergut 2004: 215-228).

If that policy made possible a quick, quantitative rise in the numbers of enlisted police after 1909, it did not suppress the concern of the institution with the low degree of morality and sense of duty prevalent among many policemen. In this respect, the criticisms voiced by police writers previously quoted were echoed by an official stigmatization of the "black sheep" of the institution through the police journals published at the time, Polis and Polis Mecmuast. Each issue of these newspapers published a list of policemen who had displayed improper behavior while performing 
their duty. Their identities, the nature of their transgressions along with their corresponding punishments were all made public (ibid.: 241). Their most recurrent faults, -consorting with prostitutes or loose women, excessive consumption of alcohol, idle time spent in coffeehouses instead of pursuing active duty-were all couched as contradictory to the moral exemplarity required by this new generation of policemen.

The public stigmatization of dishonorable policemen could have given a very negative image to the institution had not it been counterbalanced by the simultaneous exaltation of the virtue of the bravest members of the police forces. Significantly, police journals introduced their heroes to their readers in a very different manner: instead of the list's reducing individuals to their faults and penalties, the most honorable policemen were presented with their pictures and an explanatory caption. Among them, the most honored were the şehit, the policemen who had died on duty, most often while fighting brigands or robbers. Pictured within a black frame accompanied by a laudation, such brave souls were eulogized for their spirit of sacrifice and uncalculated courage..$^{13}$

The şehit were extreme cases where the social and political role which was given by the new regime to the police resulted in self-sacrifice for the nation. However, the selfnarratives of the police officers stressed that this venerable view of duty should not be the prerogative of a few individuals but rather the state of mind of all police officers:

"The police who represent the rule of justice should not hesitate to die for the service of their country when necessary, or even to go alive to the tomb. This is the most sacred aspect of their duties." ${ }^{14}$

Honor was the value underlying this spirit of sacrifice and, from a broader point of view, the everyday activities of common policemen, as summarized by the last sentences of police officer Nazıf's short self-narrative:

"Yes, my dear fellows! I beg you, I exhort you: always be honorable, because the police represent the honor of the police forces, the honor of the government, the honor of the nation." 15

31 The triptych mentioned here points to the author's expectations that the police would play the role of privileged intermediaries between the state and society, an approach that has been extensively studied by social scientists working on the police in various geographical contexts during the modern period. In this respect, the theme of honor in Ottoman sources was likewise instrumental in introducing two related notions into the field of policing: accountability and political legitimization.

The issue of accountability was crucial in the affirmation of the rupture with the old regime and promotion of a new spirit for police activities. The idea of a double accountability of the police, to the state and legal order on the one hand and the society on the other hand, constituted a break away from the understanding of policing under the previous regime. Tied to the principle of representative government trumpeted by the new regime and considered the citizens' right in exchange for their taxes, the notion of a social accountability of the police made all the more necessary the moral exemplarity of each policeman (ibrahim Feridun 1910: 61). Their honorable behavior and sound morals were not only to be checked by their hierarchy, but also to be appreciated by the various components of the urban fabric. This accountability went together with a redefinition of the police missions in terms of service (hizmet), a notion which covers a wide range of social interventions: finding lost children, helping the poor, protecting women walking on their own by night... According to Fedan Ergut, this 
emphasis on social missions bolstered by vigilant attention to accountability and political legitimation was a turning-point for the professionalization of the police institution in the early Young Turk period (Ergut 2004). ${ }^{16}$ Going beyond the protection of the individual and property, this conception of the police force lay on a much greater degree of interactions between the police and the individuals, to such extent that some authors used analogies with the family model to define the close link. In this context, the required honor of the policeman had much more to do with the honorability of a father than with the virility of soldier, and its connotations evoked more zeal and respectability than force or braveness.

Was this emphasis on social accountability and service to the people anything but a rhetorical tool used to make the institution more attractive to new recruits and more acceptable for the population? We lack primary sources to understand to what extent this professional spirit was endorsed by the policemen on the ground. It is possible to find anecdotes and instructions highlighting an increased involvement of the police forces in the service of the people (Ergut 2004: 182-184), but it is difficult to assume that they reflected everyday practices. Beyond that, the sphere of service and protection was far from including indistinctly the whole social body. On the contrary, this accountability was conceived as a duty towards deserving, respectable citizens and implied the exclusion and criminalization of the others, a dimension which I will develop more in details below. Tracing the dividing line between these two communities was one of the tasks which the police journal and textbooks assigned themselves, but the empirical nature of the police job left much space for the police members to shift the line or trace new ones when faced with concrete cases. Uncritically viewed by some authors as an Ottoman prelude to the principles of police ethics formulated in the last decades in the international arena (Bal, Beren 2003: 64-76), the emphasis on accountability was also a way for the police hierarchy to advocate and justify an increasing intervention into the everyday life of the citizens by stressing the distinct social utility of this institution. ${ }^{17}$ Central in the attempts to build a professional community, these arguments are prominently articulated in the sources under study and clearly demonstrate the political role that the police hierarchy and the government assigned to the institution.

Even when they were described in the service of the people, the ideal policemen pictured in the police textbooks were constantly reminded that they bore the huge responsibility to embody the state in their local environment. Beyond their policing tasks, it was through their exemplary behavior that, together with the gendarmes, the police were considered as vectors capable of carrying the modernizing and civilizing state project to the social and geographic margins of the empire. Significantly, late Ottoman police authors lingered less on their experiences solving crimes or arresting thieves than on the exemplary value of their daily behavior and activities among society. The greater the social or geographic distance of their "targets" from the center, the more this moralizing and civilizing mission grounded on their exemplary behavior was stressed. While they described their search for tax-evaders in the remote provinces of the Empire, or their experience policing the underground criminal networks of Istanbul, such writers denounced not only the illegal acts they encountered but also a whole range of disorderly and illicit behavior they suggested could be curbed by the police force's admonitions and exemplary conduct. ${ }^{18}$ Laziness, drunkenness, consorting with prostitutes or loose women in urban contexts, or ignorance of the Turkish language and disrespect for the public good and private 
property that they attributed to Kurdish and Arab tribes were some of the moral and social evils pointed out by late Ottoman police authors who, unsurprisingly, simultaneously portrayed themselves as well-mannered, polite and full of lessons about to the proper way to behave and foster one's integration into the Ottoman nation (Hüseyin Hakkı 1911: 18-20). ${ }^{19}$

In the context of the Second Constitutional period, that moral mission acquired a strong political character. Beyond compliance with the law or fulfilling the duties of any citizen, the police and the gendarmes were expected to reflect and spread the political values (freedom, equality, justice) promoted by the constitutional regime. This is, at least, the task they set themselves in their writings, which suggests that they had the power to make the transformations of the political system palpable in the everyday life of the common people, and thus, to play a part in the process of legitimizing the new regime. Hüseyin Hakkı (1911) illustrated this dimension with an anecdote in which he was personally involved. At his arrival at Havran, in the province of Syria, he was faced with the fearful and hostile people, who had lost any faith in the central power of the imperial government due to the misdeeds and abuses of the Hamidian police forces:

"Because of their improper behavior, their abuses which injured the human conscience and the common sense, these policemen who performed their activities in the name of the government had destroyed all the respect and consideration people had for the government and the state". ${ }^{20}$

However, after the narrator behaved mercifully to them and made a speech in which he explained the values of the new regime and the role of the gendarmes, the people immediately proclaimed their loyalty and faith in the new government:

"The criminals and the women suddenly started to shout together 'Long live to the just government". ${ }^{21}$

Needless to say, the veracity of such anecdotes is more than suspect-the organization of the narrative is closer to an apologue than to a police report, but they nonetheless constitute meaningful elements of the message their authors attempted to convey in their works. In the quoted texts, honor appears as one of the key notions that would allow the police to achieve their mission to binding subjects and instilling in them the confidence and trust of the central government. Although the semantic field of honor has a long history in the legal and political language in the Ottoman Empire, I would argue that a new dimension was added to its political meaning during the Second Constitutional period. Explicitly or implicitly, the Ottoman police writers mentioned here referred to the new challenges brought by the representative regime in terms of political legitimization. As can be seen in the last quote, in which the people celebrated "just government", the legitimization of the sultan or of the imperial political system was no longer the only issue at stake. The honorable policemen now represented not only the state but also the government, itself the emanation of the committee that dominated the political arena.

Ibrahim Feridun, Hüseyin Hakk1, and Hasan Niyazi, all authors of the works quoted above, did not hide their political affiliations. They were loyal supporters of the Committee of Union and Progress, which dominated political life in the Empire after the failed counter-revolution of 1909. These men saw themselves not only as the emanation of the state but also as defenders of the Unionists, who, they argued, constituted the only legitimate and efficient force capable of defending the regime and the society against their enemies. In this respect, their choice to take up their pen to share their experiences as police officers and to encourage the new recruits and 
promote the political and moral role of the police in the new regime should be read as political acts, as part of the CUP's larger propaganda platform launched after 1909. While promoting a view of police activity oriented towards the needs of the society rooted in exemplary behavior and interactions with the people, their writings illustrated the need to develop a political consciousness among the members of the institution that they could, in turn, inculcate to the rest of the population.

The politicization of the police institution and the gradual takeover of the CUP are beyond the scope of this article. Suffice it to say here that the Unionists did not hold a monopoly on use of the notion of honor for political ends. Its blurred and extensive definition made it a tool for different actors and institutions, with their own varying stress on the term/concept/field's moral, religious and social dimensions. Rather than what it referred to, the political impact of honor lied in its being acknowledged as a shared value that could be used in the search for a common political idiom between the state and the different components of society. However, the increasing domination of the Unionists over the political sphere and the different institutions of the state gave a specific political tone to those publications by police officers. The legitimization of power through its honorable and devoted police force went together with the discrediting of its declared or alleged opponents, accused of perverting the political, social and moral order.

\section{Separating the wheat from the chaff: the police and their "dishonorable" enemies}

As already mentioned, in the police writings under study honor did not only work as an inclusive value. The lexical field of the positive values associated with honor was frequently counterbalanced with negations of honor: şerefsiz, nâmûssuz, edebsiz. Police writers used these counter adjectives of honor to describe, construct and condemn social categories of individuals and groups that contested or threatened public or political order. The police officials' writings emphasize that an important aspect of police activity was to fight against "dishonorable" individuals and groups whom they denounced as enemies of the regime and the country-enemies who often inspired these men to write their stories down. The authors characterized their enemies in both moral and political terms and targeted police surveillance and repression towards these threats, an approach already prevalent during the reign of Abdülhamid II. Yet during the Second Constitutional era the targets of police action shifted, as increasing weight was put on different ethnic and national identities in articulating a dichotonomy between honorable and shameful citizens.

41 A closer study of the individuals and categories labeled as "dishonorable" elucidates the political and social dimensions of this stigmatization. Unsurprisingly, the fiercest criticisms were addressed to the individuals suspected of plotting against the new regime, especially those motivated by "conservative" (or "reactionary") ideals. Several chapters of the book of Riza Öge, a police officer during the Second Constitutional period and the first decade of the Turkish Republic, focus on his time spent spying on and repressing the activities of supporters of the old regime as well as members of the religious opposition (Öge 1957). While he did not give much space to the subversive political activities of such individuals, the narrator devoted long passages to their physical and moral characteristics, describing them as cunning, malicious and disloyal 
as well as denouncing in particular the influence they managed to exert over the common people through their lack of modesty and ostentatious display of religiosity. In the eyes of police officers, the purported dishonor of their opponents was part and parcel of their political ambitions of undermining the regime. This made them all the more dangerous and subversive. Although the author did not explain himself well, he suggested that their resorting to feign moral values for political ends was shameful. of course, in so doing, he ignored the fact that similar uses and abuses of morality were also at the core of the police discourse and practices of the time.

More direct attacks on the grounds of immorality targeted categories which all belonged to the lower classes and marginal groups of the cities: individuals who promote or solicit prostitutes, kabadayl ("strong-arm" men) or members of illegal bands (çete) active on the peripheries of the cities. Interestingly enough, women are almost absent from among those stigmatized categories. Whereas the police reports of the period attest to the recurrence of the interventions targeting women defined as " uygunsuz" (prostitutes, ill-reputed or improperly dressed -açık saçı- women), selfnarratives of members of the late Ottoman police do not deal with this issue. One possible explanation for this silence is that the confrontation with women would not have contributed to the construction of the authors' own positive masculinity, an important aspect of the self-promotion at work in their writings: women were described as weak creatures, whether married or single, whose security and respectability was to be protected by the police, whereas, the courage and boldness of the police affirmed themselves in their struggles against male adversaries.

Significantly, the authors of these narratives emphasized the physical strength of their opponents, often linked to their social and/or professional background, such as the Greek kayıkçı to whom Riza Öge devoted the third chapter of his book, or the ordinary prisoners who benefited from the amnesty conceded by the new regime in the summer 1908 and who were, according to Ibrahim Feridun, the cause of a tremendous rise of insecurity in Istanbul during the following months (Ibrahim Feridun 2010 (1910): 175-176). Beyond their physical characteristics, those categories were depicted as lacking any morality and honor in their use of violence: they resorted to physical intimidation and assassinations to deter or eliminate their victims for the sake of material gain and personal prestige. Rather than violence per se, its un-codified use was the target of scathing critiques by the above-mentioned authors, who charged their adversaries with attacking unarmed individuals, ganging up in large numbers on individuals, and subverting duels through the use of hidden weapons. Such were the charges that the police writers in question hurled at various members of the urban lower-classes, with the assumption that beyond their implications in specific criminal matters such individuals constituted a permanent threat for the social and moral order, both as groups and as individuals.

The kabadayl and gang label on the paper was only one aspect of the struggle for the control of urban space that the police force used to bolster its moral standing. Surveillance, police operations and incarcerations/arrests were frequently attested by period newspapers and archival sources, which betrayed the ability of these individuals and groups to challenge police authority, through violence or the use of extended social networks (Lévy-Aksu 2013: 166-170). The lack of written or oral testimoniesboth official as well as non-official-on how the rhetoric of dishonor was perceived or countered by its targets and other urban dwellers makes it difficult to measure how 
successful police discursive strategies were in actually cleansing urban settings from these allegedly subversive components.

Nevertheless, even official sources such as the police reports offer some clues that betray how this dichotomy set up between honorable policemen and dishonorable individuals did not mask the blurriness of practices on the ground, between conflict and toleration, suppression and cooperation. An extreme case testifying to the fluidity between legality and illegality, and acceptable or immoral behavior was the transformation of some individuals who were labeled as kabadayıs into police officers. The best documented case is that of Sarraf Niyazi Bey. He was one of the most famous kabadayl of the Hamidian and Young-Turk period. In 1909, he was appointed as police inspector (Serkomiser) on the main island off the coast of İstanbul, Büyükada. Several reports in the Ottoman archives note that he was charged with the task of reestablishing public order and that the terms of his appointment gave him total freedom concerning his course of action. The means used by Niyazi Bey to suppress the Greek kabadayl on the islands were typically the ones used by kabadayl in quarrels, such as fights and personal challenges between rival bands. ${ }^{22}$ Although it is not explicit in the archival material, he probably used Muslim gangs and illegal forms violence to fight the Greek gangs. By acting in such a way, he jeopardized his chances of staying in the police organization at the time of a growing codification of the duties and methods of its agents. In fact, after a shuffle in the administrative hierarchy above Niyazi Bey resulted in a visit from an inspector who found fault in his "illegal" methods in establishing order, Niyazi Bey was immediately dismissed from his position. According to Ulunay's account, Niyazi Bey then physically attacked the inspector and returned to his former life as a kabadayı. Although Niyazi Bey is an exceptional case, documented both by official documents and second-hand narratives, it suggests that the relations between the police forces and urban gangs were more complex than the official sources generally assumed in the early Young Turk period. Indicative of a certain fluidity between these two spheres, Niyazi Bey's case also brings to the forefront the role which the ethnic factor played in the determination of the honorable and dishonorable categories.

The social over-determination of the definition of dangerous groups is by no means unique to the Young Turk period nor the Ottoman context. The increasing criminalization of the lower-classes and the accusations of moral depravity which targeted them were one of the principal aspects of the process of urbanization and industrialization which took place from the late 18th century in many European and non-European countries alike. More striking in these police narratives is the combination of social, ethnic, and national criteria involved in the stigmatization of dangerous categories in an urban context. The case of the kayıkçı mentioned above offers a case in point. While he denounced the vile character and manners of two Greek brothers involved in robbery and blackmail, Riza Öge contrasted the actions of the two men to that of a Turkish kayıkçı from Rize. He portrayed the Turkish kayıkçı throughout the chapter as a most honorable man eager to defend the nation without seeking material rewards:

"I will do this job with pleasure for my country. I beg you, don't even mention money. Since we are doing this for the honor and the dignity of the state, how could I accept money to catch that pig, it would be nonsense". ${ }^{23}$

47 In Riza Öge's book, the references to the honor of the state and the nation went together with recurrent accusations against deleterious foreign influences on the 
Ottoman economy and law enforcement on the one hand and the misdeeds of Greek citizens living in the Ottoman capital on the other. Öge is an extreme case in the polarization of honor along national categories. He is also the only author whose personal narrative was not written during the Second Constitutional period but much later in 1957. His taking part in the Turkish War of Independence, during which he was seriously wounded by Greek nationalists, is presented in his preface as the turningpoint of his career and his life, a reality that makes it difficult to evaluate to what extent his nationalist rhetoric and stigmatization of Greek citizens when dealing with the pre-war period reflected his true feelings at the time, or rather, their anachronistic reconstruction within the latter framework of the nationalist ideology of the Turkish Republic. One should nevertheless mention that he carefully distinguished treacherous Greek citizens (Yunanl) from helpful Greek Ottoman subjects (Rum), whom he occasionally used as collaborators and whose taverns he frequented regularly. In this respect, his perspective fits quite well in the early stage of the Young Turk period when the stress on the nation was linked to the defense of the integrity of the Empire rather than to the condemnation of its multi-confessional and multi-ethnic character.

In other sources, the expressions the "honor of the nation" (nâmûs-ı millet) or the references to the "fatherland" (vatan) referred to the equality in rights and duties of all the Ottoman subjects and the genuine brotherhood which was to unify them. Take, for example, the following source from 1913:

"Just as Edirne is our fatherland, Istanbul, Kurdistan, Arabistan, Rumeli, Anadolu, Trablus and all the regions are parts of our country and our fatherland [...] It means that all the Muslim, Christian, Jewish Ottomans are brothers of this fatherland [...]. There should not be any division between various elements which constitute the Ottoman nations [Turkish, Arabic, Kurdish, Laz, Albanian, Tatar, Bosnian, Circassian, Rum, Armenian, Jewish, Bulgarian, Serbian and others]; they are all the sons of one fatherland, the inhabitants of one country. The more union reigns among them, the more the country and the nation progress". ${ }^{24}$

Such standard expressions of Ottomanism appeared as the official ideology promoted by these sources when defining the nation, even for the texts published in the context of the Balkan Wars of 1912-1913. The role imparted to the police forces was to maintain the integrity of the Ottoman nation through securing the lives and properties of all subjects, without any distinction of origins and through suppressing elements threatening this integrity via nationalist or separatist ambitions. The fact that none of the police textbooks published at this time mentioned the ethno-political tensions that prevailed in different parts of the Empire is surprising but can be explained in at least three respects. First, these textbooks focused mostly on the capital, Istanbul, and identified reactionary movements as the main political risk there, concentrating their attacks on the conservative and religious camps (ibrahim Feridun 2010 (1910): 177-178). Second, if we follow their arguments, the professional and political communities that they were promoting required the participation of all ethno-religious components of the Ottoman polity. Only a police institution reflecting the diversity of the nation and with a force able to speak the languages of its various members would be recognized as legitimate by the people, and therefore, be able to achieve an adequate level of control (Hasan Niyazi 1913: 44). Besides, peace between different communities was a condition for the development of police forces that were autonomous from the army but could nevertheless serve to bolster the stability of the political regime. Despite these possible justifications, one can wonder what could be the reception of these ideal views on the diversity and fraternity of the Ottoman people, which, at the time when they were 
published, were in sharp contrast both to the on-going low representation of nonMuslim communities in the police organization and the much more exclusivist nationalist stance which had been adopted by political authorities.

The increasing assimilation of the defense of the honor of the nation to the fight against its declared or alleged enemy is beyond the scope of this paper. The authors of the above mentioned works were transferred (or returned) to the army during the First World War. The military mobilization deprived the police forces of most of their recruits and introduced a break in the process of professionalization, which would only resume after the proclamation of the Republic. In this respect, military sources would probably be much more telling than police ones on the continuities and rupture in the official rhetoric of honor and its relationship with the concept of nation during the First World War and the Turkish War of Independence.

\section{Conclusion}

51 This analysis of sources written by members of the police in the early 1910's highlighted two main functions in the discursive use of honor. First, honor was a key notion in the construction of a professional identity for the institution of the post-1909 Ottoman police. It enabled police officers to fashion a rupture from the corrupt and arbitrary police of the old regime in juxtaposition to a new police ethic they promoted based on the respect for the law and service to the nation and its people. From that point of view, these sources aimed to deliver a message to present and future police recruits, providing them with representations of model characters and behaviors attributed either to the authors themselves or to other members of the police. Through their texts as well as police journals published during the period, the police engaged for the first time in corporate communication. At the core of this communication was stress on the morality of the institution, pictured as a privileged career for honorable men and as a fair, impartial and efficient tool for the protection of the people.

However, the police sources in question did not only use honor as a tool for the reform and the cohesion of the institution. The centrality of honor in their narratives was at the same time closely related to the role they attributed to the police forces in the redefinition of state/society relationship in the constitutional regime. In their view, the police embodied better than any other social group the value of honor. They portrayed their organization as an intermediary that strengthened the ties between the central power and the people through the protection of the latter and the legitimization of the former. The political dimension of this mission attributed to the police forces is explicitly or implicitly present in all of our sources: the shift to a representative regime after 1908 introduced a new dimension to the policy of legitimization of power well studied for the Hamidian regime. The state, government, and nation were used indistinctly in these sources when they defined the police as the primary guarantor of the honor of those entities. The politicization of the police forces revealed by this kind of rhetoric was even clearer in the disqualification of the enemy of the regime as immoral and disreputable. In this respect, these late Ottoman police sources offer an interesting standpoint from which to analyze the transformations of the political and public spheres in the Empire during the early Young Turk period and the shift from an initial rhetoric of integration and connection through common values to practices of exclusion and elimination. 


\section{BIBLIOGRAPHY}

\section{Primary Sources}

Ergin, Osman Nuri (1995) Mecelle-i Umûr-ı Belediyye, Istanbul, İstanbul Büyükşehir Belediyesi Kültür İşleri Daire Başkanlığı Yayınları.

Hasan Niyazi (1329 [1913]) Polis Dersleri, Dersaadet, Kasbar Matbaası.

Hüseyin Hakkı (1327 [1911]) Polis ve Jandarmalara Mahsûs Rehber, Dersaadet, Sancakciyan Matbaası.

İbrahim Feridun (1326 [1910]), Polis Efendilere Mahsûs Terbiye ve Mallûmât-ı Meslekiye, Dersaadet, Matbaa-i Hayriye; for transcription, see: İbrahim Feridun (Karakaya, Muhittin; Bilgiç, Veysel K., ed.) (2010) Polis Efendilere Mahsus Terbiye ve Malumat-ı Meslekiye, Ankara, Polis Akademisi Yayınları.

Nahum, Henri (ed.) (2002) Mis memorias, una vida yena de drama i perikolos: les mémoires de Rafael Chikurel, Istanbul, Isis.

Öge, Ali Rıza (1957) Meşrutiyetten Cumhuriyete bir Polis şefinin Gerçek Anıları, Bursa, Günlük Ticaret Gazetesi Tesisleri.

Polis (1911-1912).

Polis Mecmuası (1913-1914).

\section{Secondary Sources}

Albera, Dionigi (2006) 'Anthropology of the Mediterranean: Between Crisis and Renewal', History and Anthropology 17 (2): Re-Visioning the Mediterranean, pp. 109-133, URI: http://dx.doi.org/ $10.1080 / 02757200600633272$.

Alyot, Halim (1947) Türkiyede Zabıta: Tarihî Gelișim ve Bugünkü Durum, Ankara, Kanaat Basımevı. Badem, Candan (2010) The Ottoman Crimean War (1853-1856), Leiden, Brill.

Bal, İhsan; Beren, Fatih (2003) Polis Etiği, Ankara, Siyasal Kitabevi.

Berlière, Jean-Marc (1993) Le Préfet Lépine : vers la naissance de la police moderne, Paris, Denoël. Beşikçi, Mehmet (2012) 'Young Boys into Soldiers, the Home Front into Barracks: Attempts at Permanent Mobilization through Paramilitary Youth Organizations', in Beşikçi, Mehmet, The Ottoman Mobilization of Manpower in the First World War: Between Voluntarism and Resistance, Leiden, Brill, pp. 203-46.

Darling, Linda T. (2013) A History of Social Justice and Political Power in the Middle East: The Circle of Justice from Mesopotamia to Globalization, New York, Routledge.

Deal, Roger A. (2010) Crimes of Honor, Drunken Brawls and Murder: Violence in Istanbul under Abdülhamid II, Istanbul, Libra.

Deluermoz, Quentin (2009) 'Présences d'État : police et société à Paris 1854-1880', Annales : histoire, sciences sociales 64 (2), pp. 435-460, URL: http://www.cairn.info/article.php?

ID_ARTICLE=ANNA_642_0435. 
Deringil, Selim (2003) “"They Live in a State of Nomadism and Savagery": The Late Ottoman Empire and the Post-Colonial Debate', Comparative Studies in Society and History 45 (2), pp. 311-42, URL: http://www.jstor.org/stable/3879318.

Ergut, Ferdan (2002) 'Policing the Poor in the Late Ottoman Empire', Middle Eastern Studies 38 (2), pp. 149-164, URL: http://www.jstor.org/stable/4284230.

Ergut, Ferdan (2004) Modern Devlet ve Polis: Osmanli'dan Cumhuriyet'e Toplumsal Denetimin Diyalektiği, Istanbul, İletişim.

Esmer, Tolga U. (2009) A Culture of Rebellion: Networks of Violence and Competing Discourses of Justice in the Ottoman Empire, 1790-1808, unpubl. Ph.D dissertation, Chicago, The University of Chicago.

Febvre, Lucien (Charmasson, Thérèse; Mazon, Brigitte, ed.) (1996) « Honneur et patrie » : une enquête sur le sentiment d'honneur et l'attachement à la patrie, cours professé au Collège de France en 1945-46 et 1947, Paris, Librairie académique Perrin, URL: http://classiques.uqac.ca/classiques/ febvre_lucien/honneur_et_patrie/honneur_et_patrie.html.

Kırlı, Cengiz (2006) 'Yolsuzluğun İcadı: 1840 Ceza Kanunu, İktidar ve Bürokrasi', Tarih ve Toplum Yeni Yaklaşımlar 4, pp. 45-119, URL: http://www.ata.boun.edu.tr/faculty/Faculty/Cengiz Kirli/ Kirli Cengiz_Yolsuzlugun Icadi 1840 Ceza Kanunu (2).pdf.

Lévy, Noémi (2007) 'La police ottomane au tournant des XIX et XX siècles : les mémoires d'un commissaire d'Izmir', Revue d'histoire modern et contemporaine 54 (2), pp. 140-160, URL: http:// www.cairn.info/article.php?ID_ARTICLE=RHMC_542_0140.

Lévy-Aksu, Noémi (2013) ‘1908, une rupture ?', in Lévy-Aksu, Noémi, Ordre et désordres dans l'Istanbul ottomane (1879-1909: de l'État au quartier, Paris, Karthala, pp. 165-190.

Lévy-Aksu, Noémi (2013) 'Hommes d'honneur et homes de main : les ambigüités des kabadayl', in Lévy-Aksu, Noémi, Ordre et désordres dans l'Istanbul ottomane (1879-1909: de l'État au quartier, Paris, Karthala, pp. 253-76.

Miller, Ruth (2005) Legislating Authority: Sin and Crime in the Ottoman Empire and Turkey, New York, Routledge.

Özbek, Nadir (2009) “"Beggars” and "Vagrants” in Ottoman State Policy and Public Discourse, 1876-1914', Middle Eastern Studies 45 (5), pp. 783-801, URI: http://dx.doi.org/ $10.1080 / 00263200903135570$.

Paz, Omri (2010) Crime, Criminal and the Ottoman State: Anatolia between the Late 1830's and the late 1860's, unpubl. Ph.D. dissertation, Tel Aviv University.

Peirce, Leslie (2003) Morality Tales: Law and Gender in the Ottoman Court of Aintab, Berkeley, University of California Press.

Reinkowski, Maurus (2005) 'The State's Security and the Subjects' Prosperity: Notions of Order in Ottoman Bureaucratic Correspondence (19th Century)', in Karateke, Hakan; Reinkowski, Maurus (ed.), Legitimizing the Order: The Ottoman Rhetoric of State Power, Leiden / Boston, Brill, pp. 195-212, URL: http://www.freidok.uni-freiburg.de/volltexte/4367/pdf/

Reinkowski_The_states_security.pdf.

Rubin, Avi (2011) Ottoman Nizamiye Courts, New York, Palgrave Macmillan.

Şahin, Eyüp (2001) 1907'den 2000'e Polis Okulları, Ankara, Emniyet Genel Müdürlüğü.

Sohrabi, Nader (2011) Revolution and Constitutionalism in the Ottoman Empire and Iran, Cambridge / New York, Cambridge University Press. 
Tuğ, Başak (2009) Politics of Honor: The Institutional and Social Frontiers of "Illicit" Sex in MidEighteenth-Century Ottoman Anatolia, unpubl. Ph.D. dissertation, New York University, New York.

Üyepazarc1, Erol (2008) Korkmayın Mr Sherlock Holmes, Türkiye'de Polisiye Romanın 125 Ylllk Öyküsü, Istanbul, Oğlak Yayınları, vol. 1.

\section{NOTES}

1. For an insight into the importance of the concept of honor in Mediterranean anthropology and its critics, see Albera 2006.

2. See the introduction of Tolga Esmer's article in this special issue for an appreciation of this recent literature.

3. See also the contributions of Leslie Pierce, Başak Tuğ and Tolga U. Esmer to this special issue.

4. In this respect, police regulations follow the emphasis laid by Tanzimat legal codes on crimes against the state at the expense of crimes against individuals and property, a legal evolution which leads Ruth Miller (2005: 52-55) to consider penal codes as a central aspect of state reform and centralization during this period.

5. It also constituted a shared idiom of urban elites-notables who petitioned to the police to ask for help in the restoration of public and moral order in their neighborhoods through the expulsion of women suspected of prostitution or the closing of taverns accused of being places of excessive noise and depravations linked to the use of alcohol.

6. The Young Turk period constituted a turning point for the spread of the detective novel in the Ottoman Empire. After 1908, translations of such literature increased dramatically, and Ottoman writers such as Ebüssureya Sami, creator of Amanvermez Avni, gave their first detectives to the Ottoman literature (Üyepazarc1 2008).

7. This part is mostly based on three textbooks published between 1910 and 1913 and used in police schools: İbrahim Feridun 1910; Hasan Niyazi 1913; Hüseyin Hakk1 1911. İbrahim Feridun (1880-1938) graduated from the Imperial Military Academy (Harbiye) and started his career as a lieutenant in the Ottoman army. He taught at the academy and Police school in Istanbul during the first years of the Young Turk period. He was mobilized during the First World War, and after the end of the conflict, he retired from the army, and continued his career as an instructor in various high schools. We have less information concerning the two other authors but we learn through the forewords of their books that Hasan Niyazi was a military officer and Hüseyin Hakkı a civil official.

8. "Işte bu eski zâbıta. Ahâli nazarında hakir bir mevcûd iken kendisine kelence ahâliye karşıya emân bir kalb taşiyan bir canavar, bir zâlım, bir hâin, bir hilekâr, bir hirsız idi, firsatı 'ganimet bilen bu insaniyetsizler, efrâd-i ahâliyi esir gibi kullanıyor" (Hüseyin Hakkı 1911: 14).

9. "(Polis) benim için en zelîl ve en hakîr ve vâsıta-i zulm ve denâ'et bir sınıf mahlûkâttan ibâret idi[...] Ah nâmûssuz mahlûklar!” (İbrahim Feridun 2010 [1910]: 182).

10. "Kânûn-ı memleketi temsîl edecek, her felâkete göğüs gerecek, huzûr-ı ümmeti ve refâh-ı milleti takrîr ettirecek ancak (polis)dir, dâ'imâ arkadaşlar nâmûslu olunuz![...]" (Ibid.: 185).

11. "Zâbıta fâzilet-i 'ilmiyesiyle memleketine hizmet eder. Fakat hiç bir vakit iddi'â olunamaz ki bütün ma'nâsıyla bir zâbita me'mûru olabilmek için fâzilet-i ilmiye kifâyet eder. Ancak fâzilet-i ilmiye ile berâber bundan ziyâde hâslet-i rûhiye ve meziyet-i vicdâniye lâzım ve lâbüddür. Ahlâksızlık, ridâ'et-i rûhiye, mezellet-i nefsiye cahillere münhâsır değildir. Zâbıtanın memlekette hâdim ve nâfi olması için ma lûmâtlı olmakdan ziyâde, hüsn-ı ahlâk sâhibi bulunması arzu olunur." (Hüseyin Hakkı 1911: 22).

12. An absence of systematic purges and their variations according to the changing political agenda of the CUP have also been emphasized for other sectors of the bureaucratic apparatus, such as the provincial governors (Sohrabi 2011: 185-213). 
13. See for example the picture of an Ottoman policeman from Izmir killed on duty by bandits in Polis Mecmuast, n 13, 1 Rebi'ü-l-evvel 1332 [28 Jan. 1914], p. 296.

14. "Kanun-u adaleti temsil eden polis millet ifay-i hizmet uğrunda icab ederse ölmekten, diri diri mezara girmekten bile çekinmemelidir ve bu ise vezaifin en mukaddesidir." (Ibrahim Feridun 1910: 188).

15. "Evet, muhterem meslektaşlarım! Size yalvarır ve istirhâm ederek derim ki: dâ'imâ nâmûslu olunuz çünkü: (polis): nâmûs-ı zâbıtayı, nâmûs-ı hükûmeti, nâmûs-ı milleti temsîl eder." (Ibid.: 184-185).

16. According to Ergut, the main characteristic of the shift to modern police organizations in nineteenth-century Western Europe and the post-1908 Ottoman Empire was this conception of the police as being accountable both to the state and the people, even if there were important differences in the balance between these two poles according to the nature of the political regimes and the characteristics of their societies.

17. Focusing on the case of the Law on beggars issued in 1909, Ferdan Ergut argues convincingly that the new regime sought to increase the scope of activity and decision of the police, especially in the field of social issues. In the case of beggars, the law enabled the police to decide on the idleness and social inadequacy of individuals, and to take some repressive steps without a judicial procedure. This law, which the police hierarchy claimed during an elaboration of the law in the name of efficiency, gave legal ground to practices which, to a large extent, actually pertained to the arbitrary power of the police observable in many other contexts.

18. The geographical sphere of the police's intervention was limited to the urban areas, whereas, the gendarmes were in charge of the rest of the territory. However, the military background of many police officers had provided them with an experience in rural areas and distant provinces.

19. This derogatory approach to nomadic tribes and Eastern people of eastern Anatolia is very similar to the one pointed out by Selim Deringil for the period of Abdülhamid II (Deringil 2003: 311-342).

20. "Hükümet nâmına icrâi fa'il ve hareket eden bu zâbıta me'mûrlarının şu uygunsuzlukları vicdân-ı beşri, hizret-i nefs-i insâniyeye cürhedâr eyleyen şu sarkıntıları yüzünden ahâli 'indinde hükümet ve devletin aslâ bir ehemiyet ve "itibârı kalmamıştı" (Hüseyin Hakkı 1911: 19).

21. "Hükümete perverde eyledikleri emniyetizliğin bir i'timâd ve itminâtı olmuştu. Gerek mücrimler ve gerek bu kadınlar hepsi birden 'yaşasın 'âdil hükümet' diye bağırdılar." (Idem).

22. BOA, ZB 492/87, 29 Kânûn-ı sânî 1324 (11 Feb. 1909); ZB 384/76, 18 Hazıran 1325 (1 July 1909).

23. "Ben bu işi bu memleketim için seve seve yaparım. Kuzum kölen olayım bana paradan puldan söz etme. Madem ki Devletin şerefi ve haysiyeti için uğraşıyoruz, ben bu domuzu yakalamak için devletten para mı alacağım, olmaz böyle şey” (Öge 1957: 42).

24. "Edirne vatanımız olduğu gibi, İstanbul, İzmir, Kürdistân, Arabistan, Rumeli, Anadolu, Trablus ve bu askam dâhilindeki memâlik toprak ve de vatanmızdır. [...] Demek oluyor ki islâm, hristiyan, musevi 'umûmi osmânllar yekdiğeriyle vatan kardeştirler. [...] Osmânlı millet pencesini teşkil eden 'anâsır-i muhtelif [türk, 'arab, kürd, laz, arnavud, tatar, boşnak, çerkes, rum, ermeni, musevi, bulgar, sirb ve saire] beyninde ayrllk olmayıp hepsi bir vatanın evlâdı, bir yurdun sakinleridir. Bunlar arasinda ne derece hüsn-i ufaf ve ihtihâd husûle gelirse vatan ve millet o nisbette ka'ideler görür" (Hasan Niyazi 1913: 10-11).

\section{ABSTRACTS}

This article focuses on the use of honor and related concepts in sources written by members of the Ottoman police forces during the Young Turk period, a period that witnessed the complete 
reformation of the police institution in the Empire. It argues that the concept of honor emerged as a central value around which the promotion of individual, professional and political identities was articulated. I contend that the notion of honor, as it appears in late Ottoman police sources, was instrumental to the project of building two intricate communities, one political and the other professional. Defined as the common denominator characterizing the members of the police as well as their practices and relationships with the people, references to the value of honor also allowed police in the new Ottoman regime to stigmatize and exclude those they considered their enemies from different professional and political communities. This essay is an attempt to better understand the several layers of the rhetoric of inclusion and exclusion that surround the notion of honor, taking the police force of the early Young Turk period as its case study.

INDEX

Keywords: honor, police, 2nd Constitutional Period, professionalization, legitimization

\section{AUTHOR}

NOÉMI LÉVY-AKSU

Boğaziçi University 